\title{
Violence Against Women: \\ Psychological Trauma Phenomena that Occur in Dating Violence Victims
}

\author{
Fitri Kurnia Sari ${ }^{1}$, Sutarto Wijono ${ }^{2}$, Arianti Ina Restiani Hunga ${ }^{3}$ \\ \{fitrimenulis@gmail.com; sutarto.wiyono@uksw.edu*;ina.hunga@uksw.edu\} \\ Faculty of Psychology, Satya Wacana Christian University, Jalan Diponegoro No. 52-60 Salatiga \\ $50711^{1,2,3}$
}

\begin{abstract}
Dating can create a real hazard if there is violence involved, especially if contextualized by a world that has been constructed to privilege men. This issue cannot be separated from the patriarchal culture adhered to by most Indonesian people, where men are considered more powerful than women. This sometimes leads to violence against girls. Dating violence can occur in several forms, and it impacts both physical and mental health. Victims of violence usually experience a decrease in self-esteem, depression, anxiety, overwhelming fear and anger, somatic symptoms, to post traumatic stress disorder (Dewi, 2018). Trauma is one of the serious psychological effects experienced by victims of dating violence. Long lasting trauma, physically and mentally, changes the life of a victim. The purpose of this preliminary literature review is to explain the phenomena of trauma that occur in women victims of dating violence and build a canvas for further in-depth study.
\end{abstract}

Keywords: dating violence, victims, trauma, patriarchy, women, Indonesia

\section{Introduction}

Violence against women is increasing year by year. Data compiled by the National Commission on Violence Against Women in Indonesia shows that out of a total of 406,178 cases of violence against women compiled by National Commission on Violence Against Women in 2018, there were 392,610 cases or $96 \%$ of data from the Religious Courts (PA) and 13,568 cases or $3 \%$ is data originating from 209 service provider partner institutions that fill out and return the Komnas Perempuan data collection form. From the data based on the questionnaire it appears that violence against women in 2018 in Catahu (Perempuan, 2019) has increased by 406,178 cases, up about $14 \%$ compared to the previous year (Catahu 2018), which amounted to 348,446 .

Furthermore, the findings through the monitoring data of the Legal Resource Center for Gender Justice and Human Rights (LRC-KJHAM) recorded from 2013-2018 were 2,289 cases of violence against women with 4,427 women victims of violence. As for $50 \%$, 2,454 women are victims of sexual violence. That is, in Central Java, every day 1 to 2 women are victims of sexual violence. Wonogiri recorded 20 cases or $9.12 \%$, Salatiga, Pati and Semarang, there were 12 cases or $7.10 \%$, followed by Blora and Pekalongan with 10 cases or $2.26 \%$.

Dating violence is still less attention than domestic violence cases. Women are more victims than men because basically this violence occurs because of the imbalance of power between men and women adopted by the wider community. Injustice in terms of gender has been imprinted in everyday life, that an ordinary woman is considered as a weak, obedient, passive, prioritizing male and others, so that it is considered "appropriate" to receive unfair or arbitrary treatment. In addition, in human history, both men and women grew up in a 
world that had been constructed by the social environment since they were born. The construction cannot be separated from the patriarchal culture adhered to by most Indonesian people, where men are considered more powerful than women. This sometimes leads to violence against couples.

Dating violence occurs in adolescence. Teenagers are a transitional period between childhood and adulthood. They are in the age range of 12 years to 21 years. Students are classified as late adolescents and early adults, namely age 18-21 years and 22-24 years. Some types of emotions in the late teens are: Angry, unstable emotions, causal ways of thinking (the law of cause and effect), fear and anxiety, jealousy, a feeling of wanting with objects of other people (envy). The form of emotions that are still unstable encourages them to commit acts of violence in their dating lives. Therefore, it is necessary to immediately handle victims of violence in courtship who are on average teenagers. Because teenagers are the successor of the nation.

Violence that occurs in women's personal relationships usually consists of several types, such as attacks on physical, mental / psychological, economic and sexual. Physical aspects, violence carried out such as hitting, punching, kicking, grabbing, pinching and so on, while the mental violence against someone is usually like excessive jealousy, coercion, cursing in public and so on. Dating Violence is closely related to both short and long term health, which includes: physical injury, digestive tract disorders, chronic pain syndrome, and depressed behavior or suicide threats.

Economic violence if the couple often borrows money or other items without ever returning it, always asking for treatment, etc. If forced to be kissed by a boyfriend, if he starts to grope his body or force him to have sexual relations, then he has committed violence which is included in sexual violence. Generally the rape that occurs during courtship (Dating Rape) begins with other acts of violence. Anxiety is a response to a threat whose source is unknown, internal, vague or conflictual.

Dating violence can lead to trauma and trauma of violence still shadowing if the victim has to have a dating relationship again. Victims who have low resilience cannot respond healthy to the violence that occurs in their lives so victims who have experienced violence will find it difficult to get out of the existing cycle of violence (Primadinni, 2014).

Research conducted by (Ayu S.M, Hakimi, 2012) found that victims who experienced dating violence had psychological reactions such as feeling afraid, crying often, having trouble sleeping, hating men, not believing in men, having suspicion towards men who want to approach, and the compulsion to have sexual relations. This is reinforced by research on psychological reactions that appear as soon as individuals experience sexual violence. These include shock, disbelief, denying, feeling scared, confused, anxious, and withdrawing. Other psychological effects on victims of violence are victims often feel low self-esteem, feel guilty, embarrassed, experience sleep disorders, symptoms of posttraumatic stress disorder, and sexual problems.

(Endang Irene E, Sidabutar, Livia Iskandar Darmawan \& Poerwandari, 2003) stated that traumatic experiences shake and weaken individual defenses in facing the challenges of everyday life. Another effect that is felt when experiencing trauma is the inability of a person to control emotions. Research shows that when a person experiences trauma, there is a part of the brain that regulates emotions becoming increasingly active and uncontrolled (Barabasz AF1, Barabasz M, 2011). 


\section{Methods}

This research uses the literature review method, tracing the literature from several previous research journals about the psychological trauma phenomena that occur in dating violence victims in courtship in several areas. The study also used several books related to trauma, as well as trauma to victims of violence.

\section{Results \& Discussion}

\subsection{Symptoms of Trauma}

Knowledge of traumatic events and how the relationship of trauma symptoms to psychological and social health continues to grow. Trauma is defined as events that involve an individual as indicated by an incident that allows him to be injured or die so that a feeling of terrorism and feelings of despair appear "Trauma is defined as any event that involves the individual being exposed to the incident where injury or death was "the possibility and the feelings of terror and hopelessness are evoked" (Alien, 1995; Maxman \& Ward, 1995; Rosenbloom, Williams, \& Watkins, 1999). Accidents, natural disasters, domestic violence, sexual abuse, serious injuries, fraud, and sudden events, unexpected deaths of close friends or family members are examples of events related to trauma symptoms (American Psychiatric Association, 2013).

A person's ability to overcome - uncover traumatic events is influenced by individual and contextual factors, such as social support, personality variables, cognitive functions, the presence or absence of previous psychological conditions, behavioral capacity, and duration and intensity of trauma. The emergence of traumatic events negatively affects the physical, psychological, and emotional development of the individual itself. As a result, these people in carrying out their lives may experience various difficulties in self-esteem, assertiveness, anxiety, trust, guilt, and decision making.

Some common reactions and symptoms of psychological trauma that usually arise are:

1. Considering the painful event continuously

Many people whose minds continue to be trapped in the slump of the past. He was unable to forget a sad memory. Almost every day the memory of a bad event arises. As if the brain wants to feel that experience again and try to respond in a different way.

\section{Nightmare}

Nightmares keep coming. This shows that someone is traumatized. The system in the brain that experiences shock, even at bedtime the brain continues to process as if the event still happened. Most dreams that are experienced are not related to traumatic events. But the type is almost the same, usually nightmares are in danger, chased, and wretched. That causes disturbed sleep quality.

\section{Flashback}

People who are traumatized, in their minds dark memories often reappear. So that fear arises, lest a similar incident will occur again. Flashback is usually emotional drain, especially if the memory that appears feels so real.

4. Fear and anxiety 
Almost all trauma reactions are fear and anxiety. It feels like a scary and horrible event might happen again. Worse, this feeling can happen worse than feeling when the bad event happened.

\section{Angry}

Apart from fear and anxiety, anger usually appears as a reaction to trauma. For example, feeling angry every time you see someone who made her hurt. Can also feel angry if caught in a similar situation. He became angry faster than ordinary people. Included in the family, or the people closest to him.

\section{Sadness}

A trauma person usually responds with sadness. Often cry every time remembering a bad event that happened to her. Sadness can also come from the assumption that the world is very cruel and full of threats.

7. Feel guilty

If trauma comes from watching someone get hurt or killed, that person can feel guilty for herself. Why not do something to prevent that from happening? It can also, he feels responsible for what happens to others, as if it was his fault.

\section{Numbness}

Sometimes, a trauma person becomes numb. He turned off all kinds of emotions in her, as if he had been made from wood. Even happy emotions are not recognized by them.

9. Try to forget the event

Traumatic events are not pleasant memories, so it's natural that people who experience want to forget them.

10. Avoid anything related to that event

It can just reject people, places, even anything related to trauma. Because he considers all these things to bring her to a sad memory. For example, avoid TV shows related to that.

\section{It's hard to believe in other people}

When someone is traumatized by the treatment of others, it will be difficult to believe in others. She will be suspicious of everyone and assume that everyone has the same possibility of hurting her. Usually he formed a wall around her so that other people could not enter her life.

\subsection{PTSD (Post Traumatic Stress Disorder)}

PTSD (post-traumatic stress disorder) or post-traumatic stress disorder is a psychiatric condition that is triggered by tragic events that have been experienced or witnessed. Examples of traumatic events that can trigger this condition are traffic accidents, natural disasters, acts of crime such as rape or robbery, or experience on the battlefield. Dating violence is one of them.

PTSD belongs to the category of anxiety disorders that make the sufferer unable to forget or otherwise do not want to remember the traumatic experience, and think negatively about themselves and the surrounding world. This condition is generally characterized by nightmares, feeling isolated, upset, having feelings of guilt, difficulty concentrating, and insomnia or insomnia. 
However, not all people who experience trauma will automatically develop PTSD. This mental disorder is estimated to develop in 30 percent of people who have experienced a traumatic event. Effective treatment is very important to overcome the symptoms of posttraumatic stress disorder.

PTSD symptoms tend to interfere with daily activities, especially in relationships with other people and the work environment. Symptoms that appear on each sufferer can vary. There are those who experience it immediately after the event and some that appear after a few months or even years later.

In general, the symptoms of PTSD can be grouped into five types. The following are explanations and examples.

- Annoying memories, for example, always remember the terrible details of tragic events or often nightmares about the incident.

- The tendency to avoid talking or thinking about traumatic events. This condition is indicated by avoiding places, activities, or people that trigger memories for traumatic events.

- A mindset that changes negatively. People with PTSD tend to have negative feelings towards themselves or others, feeling alienated.

- Feeling hopeless in facing the future, having memory problems, including remembering important aspects of traumatic events and difficulties in establishing close relationships with other people.

- Changes in emotions. This change is indicated by differences in reactions both physically and emotionally, such as difficulty concentrating, feeling very always alert, easily shocked and scared.

\subsection{Post Traumatic Stress Reaction}

Violence in dating relationships in adolescents is bad for both physical and mental health. Victims of violence usually experience a decrease in self-esteem, depression, anxiety, overwhelming fear and anger, somatic symptoms, to posttraumatic stress disorder (PTSD). Victims who experience a post-traumatic reaction have the potential to experience PTSD so immediate treatment needs to be given.

Post-traumatic stress reaction is a response that occurs after an individual is exposed to a traumatic event or a group of stressful events. The American Psychiatric Association (2013) defines traumatic events as events in the form of experience or witnessing events involving death, or other threats to individual integrity, or witnessing events involving unexpected deaths, serious losses, or threats of death or injury suffered family members or other close.

Post-traumatic stress reactions experienced by victims of violence generally have symptoms similar to the main symptoms of post-traumatic stress disorder. The first symptom is a re-experience of a traumatic event. Individuals usually have intrusive and repetitive memories of the event or have nightmares. These symptoms can also cause individuals to experience flashbacks where they can feel and behave as if a traumatic event is happening (American Psychiatric Association, 2013). Individuals can suddenly feel very disturbed by things that remind of such traumatic events.

The second symptom is avoiding stimuli or things related to traumatic events (avoidance). Individuals generally will deliberately try to avoid thoughts, feelings, or 
conversations about traumatic events. The third symptom is an increase in arousal excessively, which is a physiological reaction that appears when remembered a traumatic event. Make individuals awake and have difficulty doing daily activities.

Violence in dating relationships has various terms, including Intimate Partner Violence (IPV), relationship violence, or dating violence. But the same essential thing between all the terms is all done in the context of close relationships.

Dating violence is a significant problem for adolescents who are victims. This is due to the adverse effects experienced in their lives. Apart from the physical effects such as visible wounds, there are also impacts on adolescent mental health (Callahan, M. R., Tolman. R. M., \& Saunders, 2003). Victims of courtship violence generally occur in women. However, in some cases it can also occur in men.

The traumatic experience of the victims of dating violence became very deep along with the intensity of the violence experienced by the victims and the length of the relationship between victims and KDP perpetrators. The traumatic experience experienced by victims will become increasingly difficult to cure when the victim only struggles alone in the face of the trauma experienced. Therefore intervention is also needed from other parties to help recover victims.

Trauma experienced by victims of dating violence is also one of the psychological injuries that are very dangerous for people's lives, especially teenagers, because it can reduce intellectual, emotional, and behavioral power. Trauma usually occurs when in a person's life they often experience traumatic events such as violence, rape, threats that come individually or also en masse such as armed conflict and tsunami natural disasters. Trauma can happen to anyone and at any time regardless of race, age and time. People who experience PTSD are generally haunted by traumatic experiences that they experience both directly and indirectly. Therefore, individuals who experience trauma will experience impaired thoughts, emotions, and behavior.

\subsection{Previous research on trauma symptoms in victims of dating violence}

Previous studies of trauma symptoms in victims of violence have been carried out several times. (Shen, 2013) conducted research on 1,018 students in Taiwan. This study uses self-reporting steps to collect data from national stratified random samples from 1,018 students in Taiwan. The results showed that students who experienced courtship violence reported higher levels of PTSD symptoms than those who did not. The results showed that victimization of psychological violence and cultural beliefs had a direct and indirect effect on PTSD symptoms through mediating the use of coping strategies that focused on young adults. The frequency of victimization of greater psychological violence is associated with greater use of emotional-focused coping, which in turn is associated with an increase in PTSD symptoms.

(Cohen LR, Field C, Campbell AN, 2013) found that there was a strong relationship between intimate partner violence (IPV) and post-traumatic stress disorder (PTSD) and drug use disorder (SUD). Research on the dual diagnosis of PTSD-SUD and its relationship with IPV and is known about how PTSD-SUD treatment can affect IPV results. Whereas (Primadinni, 2014) found that from seven aspects of resilience of women who experienced violence in courtship it can be seen that most victims of dating violence had low resilience. Individuals who have low resilience cannot respond healthy to the violence that occurs in their lives. So even though most victims of violence can get out of the cycle of violence that exists. However, still the trauma of violence still haunts if they have to have a dating relationship again. 
In another study, (Tri Astuti, 2012) suggested that there were six traumatic picture themes for adolescent girls, namely psychological response, cognitive response, physical response, changes in social relations, achievement of personal growth and rehabilitation of daily life. (Citra Ayu, Pratiwi, Suci Murti, Kartini, Rin Widya, 2012) states that the level of PTSD adolescents is higher than adults.

(Ekandari, Mustaqfirin, \& Faturochman, 2001) found that family support for victims of sexual violence can be in the form of emotional support, psychological support, material support, and sociological support. This support helps victims in facing the trauma they experience. Whereas (Putri, 2010) stated that there were four main themes that emerged from victims of violence as the psychological impact of sexual violence in dating relationships, namely the still felt PTSD symptoms, negative self-concept, problems in subsequent interpersonal relations, and sexual traumatization.

(Dewi, 2018) stated the results of her research, that victims of violence usually experience a decrease in self-esteem, depression, anxiety, overwhelming fear and anger, somatic symptoms, and posttraumatic stress disorder (PTSD). Victims who experience a post-traumatic reaction have the potential to experience PTSD so immediate treatment needs to be given.

From the results of these studies, it can be seen that courtship violence can cause psychological impacts in the form of trauma. The symptoms of trauma that arise on average are almost the same.

\section{Conclusion}

Based on the review of the literature above, it can be concluded that the violence that occurs in dating relationships will have a psychological impact on victims. One of these impacts is trauma. The impact can be seen from the symptoms of trauma that arise in victims of dating violence. From the results of the analysis and discussion, the trauma symptoms can be classified into several points, namely a) disturbing memories, for example, always remember the terrible details of tragic events or often nightmares about the incident. b) The tendency to avoid talking or thinking about traumatic events. This condition is indicated by avoiding places, activities, or people that trigger memories for traumatic events. c) A mindset that changes negatively. Victims of violence who experience PTSD tend to have negative feelings towards themselves or others, feeling alienated. d) Feeling hopeless in facing the future, having memory problems, including remembering important aspects of traumatic events and the difficulty of fostering close relationships with others. e) Changes in emotions. This change is indicated by differences in reactions both physically and emotionally, such as difficulty concentrating, feeling very always alert, easily surprised and scared.

In addition, some victims of dating violence who have recovered, sometimes still feel overshadowed by the trauma of violence that has ever been experienced, if they have to establish dating relationships again. The level of adolescent PTSD symptoms was indeed higher than that of adults. This is because teenagers are a transition period between childhood and adulthood, so that emotions are not too mature. There are six themes of traumatic images for adolescent girls are psychological responses, cognitive responses, physical responses, changes in social relations, achievement of personal growth and rehabilitation of daily life. In addition, there are four main themes that arise from victims of violence as the psychological impact of sexual violence in dating relationships, namely the still felt PTSD symptoms, negative self-concept, problems in subsequent interpersonal relations, and sexual traumatization. 
From this literature review it can be seen a picture of the phenomenon of trauma that occurs in victims of violence in courtship, especially women. From the discussion, for further research, this trauma problem should be followed up with continuous recovery in order to break the chain of violence in courtship that occurs. Given the victims who are still teenagers and are the next generation of the nation, determining the nation's future.

\section{References}

[1]American Psychiatric Association. (2013). Diagnostic and statistical manual of mental disorders (5th ed.). https://doi.org/10.1176/appi.books.9780890425596.744053

[2]Ayu S.M, Hakimi, H. (2012). Kekerasan dalam pacaran dan kecemasan remaja putri di kabupaten purworejo. 61-74.

[3]Barabasz AF1, Barabasz M, W. J. (2011). Single-session manualized ego state therapy (EST) for combat stress injury, PTSD, and ASD, part 1: the theory.

[4]Callahan, M. R., Tolman. R. M., \& Saunders, D. G. (2003). Religiosity, Social Support, Self-Control and Happiness as Moderating Factors of Physical Violence among Arab Adolescents in Israel. 18, 664-681.

[5]Citra Ayu, Pratiwi, Suci Murti, Kartini, Rin Widya, A. (2012). Perbedaan Tingkat Post Traumatic Stress Disorder ditinjau dari Bentuk Dukungan Emosi pada Penyintas Erupsi Merapi Usia Remaja dan Dewasa di Sleman, Yogyakarta.

[6]Cohen LR, Field C, Campbell AN, H. D. (2013). Intimate partner violence outcomes in women with PTSD and substance use: a secondary analysis of NIDA Clinical Trials Network "Women and Trauma” Multi-site Study.

[7]Dewi, W. P. (2018). Intervensi Kelompok pada Remaja Korban Kekerasan dalam Hubungan Pacaran yang Mengalami Reaksi Stres Pascatrauma. 5(1).

[8]Ekandari, Mustaqfirin, \& Faturochman. (2001). PERKOSAAN, DAMPAK, DAN ALTERNATIF PENYEMBUHANNYA. 1, 1-18.

[9]Endang Irene E, Sidabutar, Livia Iskandar Darmawan, K., \& Poerwandari, N. N. (2003). Pemulihan Psikososial Berbasis Komunitas.

[10]Perempuan, K. (2019). Catatan KekerasanTahunan Terhadap Perempuan 2019.

[11]Primadinni, A. (2014). RESILIENSI PEREMPUAN YANG MENGALAMI KEKERASAN DALAM PACARAN (STUDI KASUS PADA MAHASISWI KOST-KOSTAN DI KELURAHAN KANDANG LIMUN BENGKULU). Universitas Bengkulu.

[12]Putri, A. (2010). Rancangan Intervensi Pemulihan Trauma bagi Perempuan yang Pernah Mengalami Kekerasan Seksual dalam Hubungan Pacaran.

[13]Santrock, J. W. (2013). Life span development. New York: The McGraw-Hill Companies

[14]Safitri, W.A., 2013. Dampak Kekerasan Dalam Berpacaran. Artikel Ilmiah Hasil Penelitian Mahasiswa Unej. I(1): 1-6.

[15]Shen, T. (2013). Dating Violence and Posttraumatic Stress Disorder Symptoms in Taiwanese College Students. 
[16]Tri Astuti, R. (2012). Pengalaman Traumatik Remaja Perempuan Akibat Banjir lahar Dingin Pasca Erupsi Gunung Merapi dalam Perspektif Tumbuh Kembang di Hunian Sementara Kabupaten Magelang. 